TADEUSZ PALECZNY ${ }^{1}$

\title{
CZY MA SENS DEBATA NAD ISTOTA KULTUROZNAWSTWA?
}

Słowa kluczowe: nauki o kulturze, globalizacja, komunikacja

\section{UWAGI WSTĘPNE}

Tytułowe pytanie pada w trakcie wszystkich konferencji, dyskusji, polemik czy rozważań podejmowanych na łamach czasopism naukowych. Zadawane jest wprost bądź nie wprost w przeróżnych wariantach, sprowadzających pytanie o sens do rozpraw na temat statusu i miejsca kulturoznawstwa w dziedzinie nauk o kulturze czy ogólniej - w całej humanistyce. Pytania wynikające z wątpliwości na temat teoretycznej, w tym metodologicznej, roli kulturoznawstwa w obrębie nauk o kulturze rodzą jeszcze więcej odpowiedzi, alternatywnych bądź komplementarnych względem siebie. Nigdy jednak do końca niesatysfakcjonujących sceptyków oraz niewyjaśniających ani nierozwiewających zawartych w pytaniach kwestii spornych. Czy zatem warto i należy rozwodzić się po raz kolejny nad problemem, który wydaje się nierozwiązywalny? Czy nie jest stratą czasu podejmowanie kwestii, które stawiane są $w$ różnych kontekstach przez przedstawicieli nauk o kulturze i prowadzą do wielości różnorodnych, często sprzecznych z sobą konstatacji?

Nigdy wcześniej w trakcie ponadpiętnastoletnich studiów i badań, zaliczanych przeze mnie samego do kulturowych bądź kulturoznawczych, nie uznawałem za konieczne poszukiwania odpowiedzi na pytanie o sens własnych i cudzych przedsięwzięć naukowych. Uważałem za oczywiste,

${ }^{1}$ Prof. dr hab.; Uniwersytet Jagielloński w Krakowie;

e-mail: tadeusz.paleczny@uj.edu.pl. 
że droga poznania wiedzie przez badania i studia nad wybranymi fragmentami rzeczywistości społeczno-kulturowej i że nie ma na świecie umysłu zdolnego ogarnąć całokształt wytworów działalności ludzkiej. Sądziłem, że tożsamość dyscypliny, jaką jest kulturoznawstwo, rodzi się i kształtuje sama jako wytwór zbiorowego wysiłku ludzi reprezentujących różne podejścia, światopoglądy, teorie i koncepcje wypracowane przez różne dyscypliny naukowe. Założyłem, że kulturoznawstwo, jako dyscyplina nowa, syntetyczna, aspirująca do miana refleksji naukowej prowadzącej do uogólnień, skazane jest na przekraczanie granic pomiędzy dyscyplinami, poszukiwania nowych perspektyw epistemologicznych i właściwych do poznania dynamicznej, zmiennej rzeczywistości kulturowej rozwiązań metodologicznych. Innymi słowy, iż kulturoznawstwo obarczone jest misją wytyczania nowych kierunków studiów i badań nad kulturą oraz tworzenia i inspirowania do nowatorskich rozwiązań metodologicznych i analiz. Nadal tak uważam, jednak postanowiłem zabrać głos $w$ debacie na temat miejsca, roli i statusu kulturoznawstwa w dziedzinie nauk humanistycznych, tym bardziej że uczyniłem to w ostatnim okresie dwukrotnie.

Pierwsza debata odbyła się w czerwcu 2015 roku w auli Collegium Novum Uniwersytetu Jagiellońskiego, mojej Alma Mater, z udziałem prof. Adama Nobisa z Uniwersytetu Wrocławskiego, ks. prof. Leona Dyczewskiego z Katolickiego Uniwersytetu Lubelskiego, prof. Zbigniewa Paska z Akademii Górniczo-Hutniczej w Krakowie oraz dr hab. Małgorzaty Abbasy i dr hab. Moniki Banaś z Uniwersytetu Jagiellońskiego. Wziąłem w niej udział jako panelista i moderator. Dyskusja przyniosła wiele interesujących konkluzji, które - mam nadzieję - dotrą do szerszego kręgu odbiorców poprzez publikację na łamach czasopisma naukowego. Druga debata na temat istoty kulturoznawstwa z moim udziałem miała miejsce w Collegium Novum w listopadzie 2015 roku i uczestniczyli w niej jako paneliści prof. Jarosław Płuciennik z Uniwersytetu Łódzkiego, prof. Alina Nowicka-Jeż i prof. Eugeniusz Wilk z Uniwersytetu Warszawskiego oraz prof. Andrzej Dudek z Uniwersytetu Jagiellońskiego w Krakowie. Debaty te odbyły się z inicjatywy i inspiracji dziekana Wydziału Studiów Międzynarodowych i Politycznych Uniwersytetu Jagiellońskiego prof. Bogdana Szlachty.

Obie debaty z udziałem uczonych z wiodących ośrodków naukowych w Polsce, uważających się za kulturoznawców i zaliczanych do grona osób współtworzących tożsamość tej dyscypliny, dotyczyły w zasadzie wszystkich problemów i kwestii związanych z polemikami i pytaniami na temat statusu kulturoznawstwa. To, że wziąłem w nich udział, fakt, że w ogóle 
się odbyły, uważam za rzecz cenną i inspirującą do dalszych rozważań nad zaletami i słabościami podejścia kulturoznawczego, bo jedno jest pewne: że takie rzeczywiście istnieje. Dla mojej własnej systematyzacji podzieliłem wszelkie kwestie poruszane w tych debatach na trzy obszary.

Pierwszy dotyczył pytań o status kulturoznawstwa jako refleksji naukowej, genezy dyscypliny naukowej, jej przedmiotu i metodologii, kierunków badań, szans rozwoju, rezultatów i efektów dotychczasowych studiów i badań.

Drugi koncentrował się na stopniu i zakresie odrębności refleksji kulturoznawczej w dziedzinie humanistyki, w szczególności na relacji z innymi dyscyplinami naukowymi, zakresie interdyscyplinarności, swoistości podejścia do określania przedmiotu badań, zdolności do opisu, wyjaśnień i uogólnień w relacjonowaniu stanu rzeczywistości.

Trzeci obszar dyskusji obejmował pytania o to, co znaczy być kulturoznawcą - kwestię podmiotowości badacza i jego relacji z badanymi zjawiskami. Pojawiły się tu zagadnienia dotyczące roli i miejsca badacza kultury w relacjach z kulturą własną i cudzymi, wymogów weryfikalności wyników badań $w$ podejściu humanistycznym, rozumiejącym, sprowadzającym się do kwestii użyteczności i celowości podejścia kulturoznawczego.

Pozwalając sobie na próbę poszukiwania odpowiedzi na kilka fundamentalnych pytań na temat miejsca i roli kulturoznawstwa we współczesnej humanistyce, głównie z powodu udziału w relacjonowanych tutaj debatach, zamierzam wyrazić własny pogląd w trzech wyróżnionych powyżej obszarach.

\section{PYTANIA O STATUS KULTUROZNAWSTWA}

Powody, dla których wyłoniło się - obok antropologii, socjologii kultury, filozofii kultury, historii, wielu nauk szczegółowych, jak literaturoznawstwo, językoznawstwo, medioznawstwo, filmoznawstwo, ludoznawstwo, etnologia, etnografia, semiologia, teatrologia, historia sztuki, i paru innych - kulturoznawstwo, są liczne i złożone. Jest to moim zdaniem - oprócz prób poszukiwania i wytyczania nowych kierunków refleksji naukowej w dziedzinie nauk humanistycznych - następstwo kryzysu istniejących wcześniej nauk o kulturze, prowadzącego zarówno do krytyki sposobów i możliwości poznania przedmiotu zainteresowań, jakim jest kultura, jak i do konieczności dostosowania metod opisu i badania do szybko zmieniającej się 
rzeczywistości. Chodziło głównie o zjawiska związane z rewolucją technologiczną w zakresie komunikacji, ze zwrotem od kultury języka do kultury obrazu, powstawaniem wirtualnych cyberprzestrzeni, do których przenosiła się aktywność twórców i konsumentów kultury, o dominację popkultury, następstwa urbanizacji i megalopolizacji, uniwersalizację kulturową towarzyszącą globalizacji, wzrost znaczenia kontaktów międzykulturowych i wyłanianie się nowych modeli pluralizmu w społeczeństwach wielokulturowych. Nie sposób wymienić wszystkich zjawisk wymagających nowej refleksji, które znalazły się poza sferą albo na marginesie zainteresowań dotychczasowych dyscyplin. Faktem pozostaje, że kulturoznawstwo zrodziło się w ogniu debat o przyczynach kryzysu nauk o kulturze, jako próba - nie wiadomo jeszcze, na ile udana - w obszarze zwłaszcza propozycji epistemologicznych. Kulturoznawstwu towarzyszy alternatywna krytyka postmodernistyczna, obecna zarówno w sposobie tworzenia i funkcjonowania kultury, jak i w jej naukowym opisie i wyjaśnianiu. W alternatywnym obszarze zainteresowań naukowych rodzą się poststrukturalizm w antropologii i filozofii, transpersonalizm w psychologii, gender studies w socjologii $\mathrm{i}$ etnologii, koncepcja transgresji $\mathrm{w}$ antropologii. Przedmiotem kulturoznawstwa w sposób oczywisty staje się kultura pojęta szeroko, jako wszelkie wytwory świadomej i celowej działalności człowieka służące organizacji życia społecznego.

Niezależnie od sporów o naturę i zakres zjawisk kulturowych pomiędzy zwolennikami różnych koncepcji w kulturoznawstwie wyłoniły się dwie tendencje: inkluzywna i ekskluzywna. Pierwsza postulowała objęcie mianem kulturoznawstwa, zaliczenie do jego obszaru refleksji nad wszystkimi wytworami działalności ludzkiej. Druga redukowała, ograniczała, ba, nawet próbowała zawłaszczyć na użytek jednej dziedziny czy dyscypliny pewien zakres przedmiotowy i problemowy, np. obszar symbolu, znaku, komunikacji kulturowej (medioznawstwo, semiologia, językoznawstwo), zjawisk kreacji i tworzenia kultury (filozofia kultury, estetyka), statusu wytworów kultury (filmoznawstwo, literaturoznawstwo); inne dyscypliny kontynuowały natomiast, choć często przy krytycznym zwrocie, dotychczasowe tradycje (etnologia i antropologia, socjologia, psychologia). Niejako w poprzek istniejących i powstających dziedzin nauk o kulturze wyłaniał się nowy obszar relacji międzykulturowych, który wkomponowany był $w$ istniejące koncepcje i paradygmaty, ale jako poboczny, towarzyszący głównemu nurtowi zainteresowań statusem samej kultury. Tymczasem zjawiska towarzyszące globalizacji i uniwersalizacji, gwałtowny rozwój procesów wymiany 
kulturowej, rozwój cywilizacji, turystyki międzynarodowej, kreolizacji, hybrydyzacji, asymilacji, transkulturacji wymagały świadomego wysiłku w celu wkomponowania refleksji na ten temat do nauk o kulturze i kulturoznawstwa. Psychologia międzykulturowa, pedagogika międzykulturowa, stosunki międzynarodowe, kulturoznawstwo międzynarodowe, obecnie zaś relacje międzykulturowe - to stosunkowo nowe i świeże próby uporządkowania tej problematyki.

Konkludując: przedmiotem kulturoznawstwa jest kultura per se, we wszystkich ujęciach, bez względu na to, jak jest definiowana. Kultura występująca na różnych poziomach, jawiąca się podmiotowi poznawczemu, kulturoznawcy, jako wytwór człowieka określający jego istotę w społeczeństwie. Kulturoznawstwo uwzględnia wymiar psychokulturowy, konkretyzujący się w różnych typach i rodzajach tożsamości, także międzykulturowej, transkulturowej, na równi z wymiarem idei, zbiorowych reprezentacji kulturowych, w tym politycznych. Dalej, kulturoznawstwo koncentruje się na różnych kontekstach, znaczeniach działań ludzkich, zarówno twórczych, jak i konsumpcyjnych, kreatywnych i recepcyjnych, w ich relacjach do wartości, norm, funkcjonalności (bądź nie) w szerszym kontekście społecznym. Stąd kulturoznawstwo jako refleksja naukowa cechuje się:

- brakiem granic przedmiotowych, ontologicznych. Przedmiot zainteresowań to kultura in statu nascendi, stałe i zmienne jej obszary, przyczyny dynamiki. Każda analiza kulturoznawcza posiada swój początek i koniec w punkcie "tu i teraz", kultura jest płynną przestrzenią, w której uczony poszukuje wzorów, regularności, zrozumienia sensu funkcjonowania jej poszczególnych reprezentacji i konkretyzacji. Brak granic jest niejednokrotnie wadą, ale staje się zaletą, gdy skłania lub zmusza do poszukiwania nowych sposobów opisu i analizy zjawisk kulturowych;

- uniwersalizacją podejścia, bazującą wszakże na perspektywie lokalnej, wewnątrzkulturowej, podejmowanej z punktu widzenia badacza osadzonego „tu i teraz”. Uniwersalizacja skłania do poszukiwania podobieństw pomiędzy poszczególnymi kulturami lub ich segmentami, łącząc to, co partykularne, lokalne, z tym, co globalne, ogólne;

- łączeniem historyzmu z ahistoryzmem, znoszeniem dychotomii pomiędzy obiektywizmem i subiektywizmem, racjonalizmem i irracjonalizmem, podmiotowością i przedmiotowością podejścia. Kulturoznawstwo staje się refleksją totalną, syntetyczną, lokującą się ponad wszystkimi wodami - by użyć metafory płynącego okrętu - szeroko 
rozlanej kultury, nad rafami, mieliznami i głębinami. Chce opisywać kulturę zarówno z lotu ptaka, jak i spod powierzchni zjawisk, tak jak istnieje w wytworach i jak się jawi w ludzkiej świadomości, tożsamości, ideologii, w różnorodnych jej interpretacjach;

- wychodzeniem poza ograniczenia dotychczasowych, wąskich podejść, właściwych dla dyscyplin szczegółowych, także w stronę „piątej strony świata” bądź „czwartego wymiaru” rzeczywistości, ku cyberprzestrzeni. Kulturoznawstwo jest transgresyjne nie w sensie psychologicznym, lecz eksplanacyjnym, wychodzi, lub przynajmniej próbuje wykroczyć, poza epistemologiczne ograniczenia i metodologiczne rygory, tworząc wszakże własną aparaturę pojęciową i porządek poznawczy.

Kulturoznawstwo odróżnia się od innych dyscyplin humanistyki nie tyle przedmiotem, metodologią, co sposobem podejścia do kultury, traktowanej jako całość, przestrzeń, w której funkcjonuje człowiek jako jej twórca i odbiorca.

\section{CZY ISTNIEJE ODRĘBNOŚĆ POZNANIA KULTUROZNAWCZEGO?}

Kultura jako przedmiot poznania kulturoznawczego jest z natury rzeczy subiektywna, symboliczna, odnosi się do znaczeń i znaków, wartości i norm, funkcjonuje $\mathrm{w}$ przestrzeni semantycznej nacechowanej sensem nadawanym przez ludzi, jednostki i grupy. Poznanie kultury oznacza pytania nie o jej status ontologiczny, lecz epistemologiczny. Inaczej rzecz ujmując: poznajemy kulturę przez jej wytwory, interpretacje. Poznanie naukowe, teorie, koncepcje są immanentną częścią kultury. Interpretacja kultury, także naukowa, staje się elementem jej samej. Nauki o kulturze zawierają szereg dyskursów mniej lub bardziej szczegółowych bądź ogólnych, dotyczą tych samych zjawisk, opisywanych i wyjaśnianych z odmiennych perspektyw. Literaturę, film, teatr, kody komunikacyjne, zwłaszcza język, obyczaje, zwyczaje, wzory świętowania, kulturę polityczną, etos pracy, mit, religię, ideologię i wiele innych zjawisk można interpretować z punktu widzenia ich zasięgu, struktury, roli, znaczenia, funkcji, z pozycji uczestnika kultury bądź z zewnątrz. Pełna interpretacja zjawiska jest jednak możliwa w relacji do innych, w połączeniu z całą siecią symboli, wartości, znaczeń. Poszczególne dyskursy kulturoznawcze, przykładowo literaturoznawczy, filmoznawczy, antropologiczny czy socjologiczny, dostarczają częściowych odpowiedzi 
na pytania o miejsce i znaczenie badanego fenomenu, szatkują przedmiot poznania, dokonują fragmentacji kultury. Kulturoznawstwo poszukuje dyskursu bardziej ogólnego, wspólnego dla reprezentantów poszczególnych dyscyplin. Paradygmatowi kulturoznawczemu daleko jeszcze do teorii naukowej, jest pełen postulatów i dyrektyw, w tym instytucjonalnych, w jakimś stopniu pętających i ograniczających swobodę i wolność poznania naukowego. Instytucjonalny gorset systematyzacji nauk staje się w pewien sposób, jak dla surrealistów, czymś w rodzaju „więzienia idei”, „pułapki myśli". Kulturoznawstwo szuka wyzwolenia, ucieczki z akademickiego, tradycyjnego myślenia, nie odrzucając wszakże zdobyczy nauk szczegółowych. Zmierza o krok dalej, do syntezy, koniunkcji wysiłków wszystkich humanistów. Droga do powszechnej zgody na temat sposobów i metod badania kultury nigdy jednak się nie skończy. Fakt ten wynika z dynamicznej, zmiennej natury zjawisk kulturowych, opisywanych i badanych zarówno oddzielnie, jak i w połączeniu z innymi. Wielość i różnorodność dyskursów jest zatem koniecznym punktem wyjścia do wyznaczenia granic poznania kulturoznawczego, o ile mają one sens.

Przyjmując, że kulturoznawstwo jest w pewnym stopniu rezultatem kryzysu epistemologicznego innych nauk o kulturze (bo inaczej po co by powstało), trzeba uznać, że samo jest zapewne w dużym stopniu obciążone tą samą przypadłością. Ale kulturoznawstwo zaczyna swoją naukową refleksję tam, gdzie wyczerpują się możliwości wyjaśnienia nowych zjawisk kulturowych przez inne nauki. Kulturoznawstwo pragnie być nie tyle alternatywne, co komplementarne w stosunku do innych dziedzin i dyscyplin, poszukując zarazem świadomie - przy akceptacji swoich słabości - dróg przezwyciężenia kryzysu epistemologicznego. Ba, kulturoznawstwo zwraca uwagę na powrót kontrowersji wokół ontologicznej natury kultury, która coraz bardziej odrywa się od swojego terytorialnego, materialnego podłoża i zaczyna funkcjonować w wirtualnej cyberprzestrzeni jako nowa, pozbawiona grupowej legitymacji, religijnej sankcji, politycznej legalizacji interpersonalna sieć komunikacyjna. Jednym z bardzo moim zdaniem interesujących pionierskich przedsięwzięć na gruncie kulturoznawstwa jest właśnie podejmowanie nowych, interdyscyplinarnych badań nad internetem, wirtualizacją i wizualizacją kultury, przejściem od kultury piśmiennej do postpiśmiennej. Zaletą główną kulturoznawstwa jest to, że zostało ono uwolnione, wyzwolone z gorsetu sztywnych rygorów metodologicznych. Dzięki temu otwiera nowe kierunki zainteresowań, skłania do poszukiwania nowych metod opisu i wyjaśniania, zwłaszcza dynamiki przemian kulturowych. 
Debaty na temat rodowodu, natury i statusu kulturoznawstwa są rzeczą normalną także w obrębie samej dyscypliny. Stanowią zarówno przejaw, jak i dowód tego, że kulturoznawstwo jest dyscypliną żywą, tworzącą dopiero zręby własnej ontologii i epistemologii, wyznaczającą wolno, aczkolwiek systematycznie granice własnej refleksji teoretycznej. W konsekwencji kulturoznawstwo wkracza od razu bezpośrednio w te obszary rzeczywistości, które wymykają się dotychczas stosowanym teoriom i koncepcjom. Jak badać zjawiska Nowej Ery, przemian obyczajowych związanych z relacjami płciowymi, rewolucji technologicznej, komunikacyjnej w sieci internetowej, role nowych ruchów społecznych, zwłaszcza etnokulturowych, eksplozji konsumpcji czy międzykulturowych ruchów turystycznych przy zastosowaniu narzędzi etnografii czy antropologii? Jak opisywać i wyjaśniać zjawiska migracji w Unii Europejskiej, islamizacji, zagrożenia terroryzmem, zderzenia cywilizacji jedynie przy zastosowaniu refleksji socjologicznej? Co dzieje się z tożsamością kulturową w czasach globalnych transferów ludnościowych, kontaktów międzykulturowych? Czy do tego wystarczą koncepcje stosunków międzynarodowych, geografii czy demografii? Czy wystarczająca jest refleksja psychologów?

Kulturoznawstwo, jak każda nowa dyscyplina o cechach interdyscyplinarności, stanowi następstwo przełomu w naukach o kulturze. Przełomem tym jest powstanie nowej przestrzeni semantycznej, nowego obszaru rzeczywistości, jakim jest cyberprzestrzeń, wirtualna sieć internetowa. Sam internet jest transgresją kulturową, przekroczeniem tradycyjnych - opartych na tekście pisanym, na zwartym kodzie komunikacyjnym, jakim jest język granic systemów symboliczno-normatywnych. Wynalezienie i upowszechnienie internetu pociąga rewolucyjne przemiany kulturowe o konsekwencjach o wiele większych i poważniejszych niż wynalezienie druku. Kulturowa "galaktyka Gutenberga” ustępuje miejsca „galaktyce McLuhana”, kultura piśmienna wypierana jest przez kulturę wizualną, multimedialną. Czy nauki o kulturze, zwłaszcza szczegółowe, gotowe są do stawienia czoła nowym wyzwaniom? Czy kulturoznawstwo nie winno stać się wspólnym forum poszukiwania odpowiedzi na fundamentalne pytania o status, naturę i mechanizmy przemian kultury? Czy nie jest ono szansą i możliwością poszukiwania pomostów pomiędzy różnymi teoriami i koncepcjami, pociągającymi za sobą wielość stanowisk, szkół, definicji i podejść do badań nad kulturą? Są$\mathrm{dzę,} \mathrm{że} \mathrm{dla} \mathrm{dobra} \mathrm{humanistyki} \mathrm{nie} \mathrm{tylko} \mathrm{warto,} \mathrm{ale} \mathrm{też} \mathrm{należy} \mathrm{jednoczyć} \mathrm{wy-}$ siłki w poszukiwaniu tego, co łączy nauki o kulturze, a nie tego, co je dzieli. Łączy zaś wspólny przedmiot oraz cel, użyteczność poznania naukowego. 


\section{CO TO ZNACZY BYĆ KULTUROZNAWCĄ?}

Jak każdy badacz kultury, zadaję sobie coraz częściej pytanie o to, do jakiej dyscypliny należy mój dorobek. Jaką dziedzinę reprezentuję? Jakie znaczenie i sens mają moje badania, studia i działalność dydaktyczna? Pytania te rodzą się z jednej strony z powodu ustawowych, prawnych zmian w zasadach systematyzacji nauk, z drugiej z potrzeby identyfikacji samego siebie z jakąś tradycją teoretyczną, szkołą naukową, podejściem metodologicznym. Kulturoznawstwo obejmuje różne dyscypliny, w tym socjologię kultury czy historię, posiada obszary wspólne z psychologią, prawem czy ekonomią i zarządzaniem. Immanentnym elementem poznania kulturoznawczego jest badanie kodów i systemów symbolicznych, właściwych dla nauki o literaturze, językoznawstwa, teatrologii, filmoznawstwa i paru co najmniej jeszcze dyscyplin szczegółowych. Co to znaczy być kulturoznawcą? Skoro jestem z wykształcenia socjologiem kultury, zajmuję się między innymi socjologią narodu, stosunków etnicznych, komunikacji międzykulturowej - to czy jestem kulturoznawcą? Dlaczego w ciągu ostatnich kilkunastu lat nie tyle odszedłem od socjologii w wąskim tego słowa znaczeniu, co wykroczyłem poza jej perspektywę i metody w kierunku poznania kulturoznawczego? Czy nie łatwiej jest pozostać socjologiem? Jaka potrzeba czy jaki cel powoduje, że poszukuję innych sposobów opisu i badania tej samej rzeczywistości? Czy wyjście poza socjologię i jej paradygmat ogranicza i redukuje moje możliwości intelektualne i stwarza bariery dla skutecznego poznania naukowego? Czy możliwe jest łączenie doświadczenia socjologicznego, antropologicznego i kulturoznawczego w biografii jednego uczonego?

Nie znajduję gotowych wyjaśnień ani odpowiedzi na pytanie o to, co sprawiło, że będąc socjologiem, stałem się także kulturoznawcą. Nie muszę ich szukać. Odpowiedź znajduję w codziennym działaniu, w praktyce naukowej, w dydaktyce i badaniach nad kulturą. To kultura stawia wyzwania, skłaniające do nadążania za jej przemianami. Rzeczywistość wyznacza nowe problemy badawcze i teoretyczne, które wymagają innego spojrzenia, odmiennej od dotychczasowej perspektywy. Wkraczając w obszar poznania kulturoznawczego, dołączam do nowego dyskursu, ale nie porzucam starego. Staram się przezwyciężyć słabości metody ilościowej, zdając sobie zarazem sprawę z niedoskonałości analizy jakościowej. I na odwrót, stawiając sobie konkretny cel badawczy, na przykład tempo asymilacji imigrantów, poszukuję odpowiednich narzędzi zarówno jako socjolog, jak i jako kulturoznawca. Nie widzę zazwyczaj sprzeczności w obu równoległych, równoczesnych 
i komplementarnych podejściach, a jeżeli stają się one alternatywne, to na mocy konwencji naukowej, rygorów pojęciowych i metodologicznych. Cóż wtedy pozostaje? Próba połączenia w nowym podejściu zalet jednej i drugiej dyscypliny, usuwania sprzeczności wynikających z założeń teoretycznych. Punktem wyjścia do analizy kulturoznawczej staje się praktyka społeczna, użyteczność i celowość wyjaśnienia naukowego. Innymi słowy, jako kulturoznawca stawiam sobie zawsze pytanie, czemu opis, analiza i badanie zjawisk kulturowych ma służyć - jaki użytek przyniesie konkretne przedsięwzięcie badawcze. Jako kulturoznawca nie jestem reprezentantem jednej dziedziny, nie poszukuję rozwiązań w koncepcjach czy teoriach zaliczanych do jednej dyscypliny, przykładowo socjologii czy psychologii. W podejściu do przedmiotu poznania naukowego jako kulturoznawca sięgam po wszelkie teorie i metody, które wydają mi się użyteczne i efektywne w opisach i analizach. Nie wytyczam granicy pomiędzy podejściem antropologicznym, historycznym czy filozoficznym, nie rezygnuję z założeń strukturalizmu, historyzmu czy funkcjonalizmu. Jeżeli wymaga tego przedmiot badań, jak choćby analiza nowych typów tożsamości w cyberprzestrzeni, kreowanych w sieci nowych układów symbolicznych, nieznanych wcześniej rodzajów więzi społecznej, wychodzę w formułowaniu celów badawczych poza granice socjologii czy etnologii. Bycie kulturoznawcą oznacza porzucenie pewnego miejsca w obrębie jednej dyscypliny, przyjęcie innej, interdyscyplinarnej orientacji, kształtowanie nowej formy wrażliwości poznawczej. Jak twierdzi Jacek Sójka, inicjator i uczestnik publicznej debaty nad statusem kulturoznawstwa:

Kulturoznawczy punkt widzenia służy nie tylko czysto teoretycznym rozważaniom. Jedną z możliwości aplikacji jest polityka kulturalna, o czym w Polsce nie zawsze się pamięta. Projekty w tym względzie nie mogą być oderwane od teoretycznego rozumienia kultury, o ile nie mają być jakąś urzędniczą fanaberią. Inną są projekty edukacyjne mające na celu budowanie tzw. społeczeństwa informacyjnego, realizowane przez organizacje lokalne i międzynarodowe ${ }^{2}$.

Polityka kulturalna jest zespołem dyrektyw i działań, służących także systematyzacji dziedzin i dyscyplin naukowych. Kulturoznawstwo ma ambicję integrować wszystkie nauki o kulturze nie po to, by wypierać je z przestrzeni publicznej i zajmować ich miejsce w dyskursie politycznym, lecz po to, by dostarczać pełniejszej, bardziej syntetycznej wiedzy wszystkim,

2 J. Sójka, Kulturoznawstwo - od znawstwa do dyscypliny naukowej, "Nauka” 4, 2005, s. 116. 
którym leży na sercu dobro kultury. Zarówno twórcom, organizacjom i instytucjom kultury, jak i jej odbiorcom.

\section{NOTKA BIBLIOGRAFICZNA}

Debata nad miejscem, statusem i rolą kulturoznawstwa w naukach humanistycznych trwa od kilkunastu lat. Zabierali w niej głos czołowi humaniści polscy, reprezentanci różnych dyscyplin z zakresu nauk o kulturze. Tożsamość kulturoznawstwa jest wciąż przedmiotem polemik, dyskusji, czymś, co stale podlega negocjacjom i ustaleniom. W wymiarze instytucjonalnym, akademickim kulturoznawstwo pozostaje dyscypliną nową, poszukującą miejsca w naukach o kulturze. Jest młodszą siostrą filozofii kultury, etnologii, socjologii, historii, nauk o sztuce, jak również dyscyplin szczegółowych, literaturoznawstwa, językoznawstwa, wszystkich zaliczanych do dziedziny humanistyki i nauk o kulturze. Ma już swoje struktury uniwersyteckie, instytuty i katedry, kierunki i specjalności studiów. Kilka ośrodków w Polsce posiada uprawnienia do nadawania stopnia doktora i doktora habilitowanego $w$ dyscyplinie. $W$ toku debat i dyskusji ścierają się różne szkoły, nurty i koncepcje, wyrastające na gruncie różnych orientacji teoretycznych. W omawianych debatach wzięli i biorą udział reprezentanci najważniejszych ośrodków uniwersyteckich w Polsce. Dorobek i doświadczenia tych środowisk akademickich wyrażane w debacie skłaniają do optymistycznych wniosków o możliwości dalszej integracji, ustalenia wspólnych założeń, kierunków studiów i badań, jednak bez konieczności wyznaczania sztywnych granic i kanonów dyscypliny.

Niezależnie od sądów wyrażanych przy okazji spotkań i konferencji istnieje już spora literatura przedmiotu, systematyzująca i syntetyzująca dotychczasowe ustalenia na temat statusu i tożsamości kulturoznawstwa. W selektywnym przeglądzie pozycji bibliograficznych pomocnych przy określaniu, czym jest kulturoznawstwo i jakie jest miejsce tej dyscypliny w dziedzinie nauk humanistycznych, uwzględniłem zarówno pionierskie polskie opracowania naukowe, jak i najnowsze monografie. Przegląd bibliograficzny jest oczywiście dalece niepełny, autorski, subiektywny, dokonany z punktu widzenia kulturoznawcy wywodzącego się z nauk społecznych, o dorobku z zakresu stosunków międzykulturowych.

Za szczególnie przydatne $w$ debatach nad statusem kulturoznawstwa uważam następujące prace: monografię zbiorową z 1995 roku pod redakcją Jacka Sójki o tytule Perspektywy refleksji kulturoznawczej (Wydawnictwo 
Fundacji Humaniora, Poznań 1995), numer monograficzny czasopisma „Kultura Współczesna" z 1999 roku (nr 2) pod redakcją Jacka Sójki i Anny Zeidler-Janiszewskiej oraz opracowanie zbiorowe Wiedza o kulturze polskiej u progu XXI wieku pod redakcją Stefana Bednarka i Krzysztofa Łukasiewicza (Kongres Kultury Polskiej, Wrocław 2000).

Z nowszych opracowań za warte polecenia uznaję następujące prace: artykuł Jacka Sójki z 2005 roku zatytułowany Kulturoznawstwo - od znawstwa do dyscypliny naukowej („Nauka” 4, 2005, s. 97-116), publikacje Chrisa Barkera Studia kulturowe. Teoria i praktyka (przeł. Agata Sadza, Wydawnictwo Uniwersytetu Jagiellońskiego, Kraków 2005) i Jerzego Kmity Późny wnuk filozofii. Wprowadzenie do kulturoznawstwa (Bogucki Wydawnictwo Naukowe, Poznań 2007), książkę współautorstwa Elaine Baldwin, Briana Longhursta, Scotta Mccrackena, Milesa Ogborna i Grega Smitha Wstęp do kulturoznawstwa (przeł. Maciej Kaczyński, Jerzy Łoziński, Tomasz Rosiński, Zysk i S-ka Wydawnictwo, Poznań 2007), monografię zbiorową pod redakcją Wojciecha Burszty i Michała Januszkiewicza Kulturo-znawstwo. Dyscyplina bez dyscypliny? (Wydawnictwo SWPS Academica, Warszawa 2010), omówienie Eugeniusza Wilka Kulturoznawstwo - realizujq̨cy się projekt („Przegląd Kulturoznawczy” 2(12), 2012, s. 209-211) oraz najnowsze opracowanie o charakterze podręcznika akademickiego autorstwa Aleidy Assman - Wprowadzenie do kulturoznawstwa. Podstawowe terminy, problemy, pytania (przeł. Anna Artwińska, Katarzyna Różańska, Wydawnictwo Nauka i Innowacje, Poznań 2015).

\title{
DOES IT MAKE SENSE TO DEBATE THE ESSENCE OF CULTURAL STUDIES?
}

\begin{abstract}
The article raises a number of questions regarding the purpose of developing new approaches in research on culture. One of them is provided by cultural studies. The rapidly changing reality due to globalisation processes, high technologies and modern forms of communications, inter alia, has forced us to modify and work out new forms of description. New cultural studies constitute, on the one hand, opposition to traditional cultural sciences, while, on the other hand, becoming complementary in the areas in which the traditional approach has proved to be insufficient with its methodological, epistemological, axiological or terminological resources.
\end{abstract}

Key words: cultural sciences, globalisation, communication 